\title{
The Romantic Conventions of the "Haunted Melodrama"
}

\author{
By Zachary Z. E. Bennett
}

Fall 2009 Issue of KINEMA

\section{THE ROMANTIC CONVENTIONS OF THE "HAUNTED MELODRAMA"}

THE NEXUS between love and death has been fodder for artists at least since antiquity. In Greek mythology, Orpheus famously descended into Hades in a fruitless attempt to retrieve his wife Eurydice from death. In his Divine Comedy, Dante Alighieri, after passing through hell and purgatory, is guided through paradise by his beloved Beatrice. The human preoccupation with the twin forces of love and death was best (and most frequently) expressed, however, by the artists of the Romantic movement. In more recent history, artists and directors working in the field of cinema resurrected many Romantic conventions in treating the same subject matter. Their collective work can be roughly collected into a film genre known as "haunted melodrama."(1)

Before exploring the application of Romantic conventions to haunted melodramas, it is first necessary to establish the philosophical foundation of these Romantic conventions. In his quasi-pedagogical treatise The Philosophy of Composition, Edgar Allan Poe explained how he conceived his most famous poem, "The Raven." He said:

Now, never losing sight of the object supremeness, or perfection, at all points, I asked myself - 'Of all melancholy topics, what, according to the universal understanding of mankind, is the most melancholy?' Death - was the obvious reply. 'And when,' I said, 'is this most melancholy of topics most poetical?' From what I have already explained at some length, the answer, here also, is obvious - 'When it most closely allies itself to Beauty: the death, then, of a beautiful woman is, unquestionably, the most poetical topic in the world - and equally it is beyond doubt that the lips best suited for such topic are those of a bereaved lover.'(2)

This principle that Poe outlined in the first half of the nineteenth century is still valid today. The death of a beautiful woman is a theme that appears repeatedly in haunted melodramas, perhaps most notably in Anglo-American director Alfred Hitchcock's magnum opus, Vertigo.

Hitchcock is best remembered as a master of suspense and psychological horror, and Vertigo clearly overlaps with those genres, but no intelligent viewer could possibly overlook the correlation between Poe's statement above and the behaviour that Jimmy Stewart's character, John ("Scottie") Ferguson, exhibits in Vertigo. The plot itself begins in a somewhat typical film noir-ish style, as Scottie is hired to do some private investigating for an old friend who claims that his wife has been possessed by the spirit of a dead woman. This pseudosupernatural element, combined with the surrealistic (and metaphorically significant) atmosphere of the film, marks Vertigo as a haunted melodrama. Although there is no bona fide supernatural activity in the movie, Hitchcock borrows from the postmodernist notion that perception is reality: Scottie's perceptions of the events around him mould not only his experiences as a character but also the audience's experience, and the film's overarching theme. That is to say, although Madeline is not really Madeline but rather Judy, and although Judy isn't really dead (until the dénouement), Scottie believes Madeline is dead and has returned, almost as though she were reincarnated.

Edgar Allan Poe used a similar device in his short story "Ligeia." In that story, the narrator is a man whose wife, the title character, dies. He remarries another woman, Rowena, and at the climactic ending Ligeia, refusing (even in death) to be replaced by another woman, possesses the body of Rowena and, in so doing, drives the narrator mad. ${ }^{(3)}$ The correlations between Poe's tale and Hitchcock's film are obvious. The "possession" of the living woman by the dead woman is a variation on Poe's aforementioned "death of a beautiful woman" theorem of the artistic Sublime. In Vertigo, it appears in a non-supernatural context, insofar that all of the ostensibly supernatural elements are eventually explained away.

Vertigo's mode of dealing with the supernatural harks to the Gothic romance novels of Anne Radcliffe, in which seemingly otherworldly occurrences are invariably proven to be the results of mundane phenomena. Such an approach is known as the "supernatural explained." Works of art in which the supernatural is not 
explained away (as in "Ligeia," for example) are conversely known as the "supernatural accepted." Both of these approaches are valid, and both are effective within the genre of haunted melodrama. Likewise, each draws directly from Romantic influences: "supernatural explained" descends directly from Radcliffe, and "supernatural accepted" directly from other Romantics, including (at least in the case of "Ligeia") Poe.

As an artistic work of the "supernatural explained" school, Vertigo draws from a very long line of Romantic works, including Poe's "The Raven" and Samuel Taylor Coleridge's "The Rime of the Ancient Mariner." Both of these poems, one by an American and one by a Briton, are examples of high Romanticism, and both represent the human tendency to assign supernatural significance to ordinary events. In "The Raven," the speaker (the dead Lenore's bereaved lover) encounters a raven that has learned by rote how to say one word: "nevermore." Because the speaker is consumed with mournful melancholia, he asks the raven if he will ever see his lost love. Although the bird answers with "nevermore" simply because that is the only word it can speak, the man imputes a supernatural significance to the answer, irrationally believing the bird to be a sentient being. ${ }^{(4)}$ Likewise, in Coleridge's "The Rime of the Ancient Mariner," the title character relates a story of how he killed an albatross during a sea voyage and his shipmates, who saw the bird as a good omen, irrationally blame him for the failure of their ship's sails to catch wind. ${ }^{(5)}$

In Vertigo, Scottie is tricked into believing that the events going on around him are in fact supernatural, but he comes to accept this idea because of a predisposition that he has toward mysticism. This predisposition is a trait that Scottie has inherited from his Romantic ancestors, including the speaker in "The Raven" and the title Mariner in Coleridge's "Rime." Early in the film, when Gavin Elster hires Scottie and claims that his wife is possessed, Scottie tells Gavin that he should consult a psychiatrist, ${ }^{(6)}$ but this initial disbelief doesn't last long. In the scene at Scottie's apartment after Scottie rescues Judy (whom he believes to be Madeline) from "falling" into the San Francisco Bay, he asks her if she has memory lapses on a frequent basis. ${ }^{(7)}$ The fact that he even poses this question proves that he has already begun at least to entertain the idea that "Madeline" may be possessed, as Gavin had claimed. Scottie's credulity further increases during the scene in the redwood forest, when Judy/Madeline runs her forefinger across a small piece of a tree trunk bark, saying: "Here I was born, and there I died. It was only a moment for you; you took no notice."(8)

The dreamlike atmosphere of the film only adds to the sense that Scottie is at least a masochistic fool, if not a self-willed victim. He can sense that "Madeline" is dangerous, but he cannot resist her. This fact becomes salaciously obvious when she awakes in his apartment after either falling or pretending to fall into the San Francisco Bay. He has removed her wet clothes and placed her in his bed. This scene proves that Scottie is less than perfectly innocent. In fact, it implies a sort of sexual perversity on his part; undressing a woman that he has never even met while she is unconscious suggests that Scottie is not the gentleman that Jimmy Stewart portrays him to be. A rational viewer could easily infer (albeit without substantial evidence to either prove or disprove the idea) that this sexual deviance accounts for why Midge broke her engagement with Scottie some time previously.

One highly sexualized and yet confusing scene appears very early in the film between Midge and Scottie:

Scottie: What's this doohickey?

Midge: It's a brassiere! You know about those things, you're a big boy now.

Scottie: I've never run across one like that.

Midge: It's brand new. Revolutionary up-lift: no shoulder straps, no back straps, but it does everything a brassiere should do. Works on the principle of the cantilevered bridge.

Scottie: It does?

Midge: An aircraft engineer down the peninsula designed it; he worked it out in his spare time.

Scottie: Kind of a hobby, a do-it-yourself kind of thing. ${ }^{(9)}$

This discussion about innovations in the design of women's undergarments seems to have no relevance to the plot whatsoever. Why, then, does Hitchcock keep it in the film? The only possible explanation is that he wants to establish a subliminal understanding in the audience that Scottie is not just some straight-laced ex-cop; he is a sexualized character.

Scottie's implied sexual deviance marks him as a Freudian male. Both fascinated by and fearful of the concept of Woman per se, he attempts (ultimately in vain) to become the master of the woman whom he 
loves. This fact becomes strikingly obvious in the movie after the original bell tower scene. After he meets Judy as herself (i.e., not disguised as Madeline) he proves his sexualized obsessive-compulsiveness over and over again. In one bit of dialogue between the two characters, Scottie obsesses over changing Judy into Madeline, moulding her to his will:

Judy: Couldn't you like me, just me the way I am? When we first started out, it was so good; we had fun. And...and then you started in on the clothes. Well, I'll wear the darn clothes if you want me to, if, if you'll just, just like me.

Scottie: The colour of your hair...

Judy: Oh, no!

Scottie: Judy, please, it can't matter to you. ${ }^{(10)}$

This repartee is simply bizarre. In the face of Judy's impassioned emotional appeal for his love, Scottie can only think about dying her hair to make it look more like Madeline's. This scene reveals yet another dimension to Scottie's sexual deviance: he is a fetishist. Like all fetishists, he sees the object of his desire as exactly that - an object, nothing more. Much like the speaker in "The Raven," Scottie is obsessed with a woman that (he thinks) has died, and the world of the living can offer him no relief for his grief-stricken longing. As the typical Freudian male, Scottie has the compulsion to repeat; he attempts to repeat his love affair with "Madeline" by turning Judy (back) into Madeline, and much like the artificial tragic ending in the initial bell tower scene, the second affair's ending repeats the tragedy of the first.

The film's dramatic dénouement is quintessential of Romantic tragedy. The male hero loses the object of his desire, and he does so, at least partially, because of his own imperfections as a character. Blinded from his love of Judy by his feelings that he has been betrayed by her, Scottie attempts to reassert his control over her, this time not by choosing her clothing, but by re-enacting the scene in the bell tower. As he looks down at the semi-spiral staircase, the camera zooms in and out, creating a strong sense of unease. This camera work is applied sexual metaphor. The empty space in the middle of the stairwell is a deep, abysmal chasm a symbolic Freudian vagina. This suggests that Scottie's real fear is not of heights per se, but of women and their power over him.

As Scottie forces Judy to the top of the stairs, he is attempting to assert masculine dominance over not only his female love interest, but also the aforementioned feminine setting of the bell tower. As he does so, he is slipping deeper and deeper into dementia. He has already been metaphorically emasculated once before in the movie, during the inquest that investigated the circumstances of Madeline's death. At that time, the coroner strongly implied that the death was Scottie's fault because he was too weak to control the events around him. In the coroner's words, "He did nothing. The law has little to say on things left undone." (11) This language strongly suggests impotence, both literally (in the broad definition of "impotence") and figuratively (in the sexual sense). After suffering that defeat, Scottie is determined to redouble his efforts to assert his masculinity, which he does in the final scene. In asserting his masculinity, however, he causes the death of the woman he loves.

The appearance of the nun after Judy falls to her demise is extremely telling. As a symbol of traditional religion, the nun is also a symbol of the superego. She appears immediately after Judy's death as if she is the personification of Scottie's conscience, telling him that this tragedy is his fault. In Scottie's perception, it was his unmanly and pusillanimous vertigo that (seemingly) prevented him from saving Madeline in the first bell tower scene. By contrast, his vaunting masculinity served as the catalyst for Judy's death in the second bell tower scene. In the vernacular cliché, Scottie is damned if he does and damned if he doesn't.

A critical analysis of Vertigo reveals that Scottie Ferguson is a character descended from the finest traditions of high Romanticism. His sexual anxiety is reminiscent of any number of male heroes in Romantic poetry and prose. Moreover, the obvious nexus between the themes of love and death firmly situates Vertigo within the genre of haunted melodrama. Although the initial death is partially a ruse, the perception of the audience must be the governing factor in deciding whether death is a significant theme. Because Scottie is the principal sympathetic character and the audience largely shares his point of view, and because in his perception Judy's death is real in both bell tower scenes, the theme of what Poe called the "death of a beautiful woman" is very much at the core of this haunted melodrama. 


\section{Notes}

1. Richard Striner, Ph.D., lectures on "haunted melodrama," Washington College, Goldstein Hall, Room 100, spring term 2006. Dr. Striner is to be credited with distinguishing the "haunted melodrama" as a unique genre.

2. Edgar Allan Poe, Complete Poems and Selected Essays, ed. Richard Gray (London: Everyman, 1999), 109.

3. Edgar Allan Poe, "Ligeia."

4. Edgar Allan Poe, "The Raven."

5. Samuel Taylor Coleridge, "The Rime of the Ancient Mariner," in English Romantic Poetry and Prose, ed. Russell Noyes (New York: Oxford UP, 1967), 392-401.

6. Vertigo, video, dir. by Alfred Hitchcock (1958).

7. Ibid.

8. Ibid.

9. Ibid.

10. Ibid.

11. Ibid.

\section{References}

\section{Bibliography}

Striner, Richard. Lectures on "haunted melodrama." Washington College, Goldstein Hall, Room 100. Spring term 2006.

Coleridge, Samuel Taylor. "The Rime of the Ancient Mariner." In English Romantic Poetry and Prose, edited by Russell Noyes, 392-401. New York: Oxford UP, 1967.

Poe, Edgar Allan. "Ligeia."

Poe, Edgar Allan. Complete Poems and Selected Essays. Edited by Richard Gray. London: Everyman, 1999.

Vertigo. Videotape. Directed by Alfred Hitchcock. 1958.

\section{Author Information}

Zachary Z. E. BENNETT received his B.A. degree from Washington College in Chestertown, Maryland in. He works as an independent researcher in literature and film, currently pursuing a graduate degree in English. 